Open Access

\title{
Natural disasters and deterrence of economic innovation: a case of temporary job losses by Hurricane Sandy
}

\author{
JiYoung Park ${ }^{1 *}$, Minsu Son ${ }^{2}$ and ChangKeun Park ${ }^{3}$
}

\author{
* Correspondence: \\ jp292@buffalo.edu \\ ${ }^{1}$ Department of Urban and Regional \\ Planning, University at Buffalo, 228 \\ Hayes Hall, Buffalo, NY 14214-3087, \\ USA \\ Full list of author information is \\ available at the end of the article
}

\begin{abstract}
Quantifying many natural disasters economically is a global concern. Even in the U.S., economic damages stemming from natural disasters are experienced annually. Unexpected natural disasters result in various economic and business management disruptions. Especially, complex inter-industrial and inter-regional connections in established economies may experience much larger impacts by a disaster, and hence, the economic and business losses need to count not only the direct, actual lost value of business during the disrupted period, but also the indirect, latent lost value that would not have occurred. In the U.S., severe economic damages generated by the two hurricanes that hit the Gulf of Mexico in August 2005 were recorded in the history; however, this hurricane-generated economic loss is still being experienced. Hurricane Sandy occurred in 2012 is recorded as one of the largest storms ever to mash American territory. The hurricane-caused disruptions of metro built environments and natural environmental systems demonstrated how fragile New York City (NYC) and Long Island areas are from hurricanes and storm surges. This promptly generated a new discussion of building coastal barriers surrounding the shorelines of the areas, expecting to minimize the destructive risk from a similar event in the future. An issue that was not seriously explored in this discussion is how to account for economic damages more extensively and accurately. Majority studies of estimating economic damages rely on governmental reports that mostly focus on the magnitude of building losses directly damaged or on speculations about future impacts on the area already damaged. However, when considering inter-industrial and inter-regional economic connections which are becoming more complicated, accounting for the indirectly connected ripple impacts is important in the market economies because recovery from economic damages requires an understanding of resilient paths of the lost business production. This study provides a procedure to estimate a type of interconnected economic damages based on the National Interstate Economic Model (NIEMO) and the temporarily lost jobs using Census data during the first 4 days caused by Hurricane Sandy. By tracing Sandy's moving path from Florida to New Hampshire, it was found that Sandy had brought another tragedy mainly to the NYC and Long Island areas, reaching $\$ 2.8$ billion in 4 days with 99\% of the loss occurring in the last day of Sandy. Furthermore, the national impacts attained $\$ 10$ billion losses according to the NIEMO analysis. Technological innovation that may support various mitigation and prevention policies would reduce the economic losses, expediting recovery to the normal status of U.S. economy.
\end{abstract}

Keywords: Hurricane Sandy, Economic innovations, National Interstate Economic Model (NIEMO), Temporary job losses 


\section{Introduction and issues}

Quantifying numerous natural disasters economically is an increasingly common interest in the U.S. as well as a global concern. Even in the U.S., economic damages stemming from natural disasters are experienced annually (Richardson et al., 2014; Park et al., 2014a). Unexpected natural disasters result in various economic and business management disruptions. Complex inter-industrial and inter-regional connections in established economies may experience much larger impacts by a disaster, and hence, the economic and business losses need to include not only the direct, actual lost value of business during the disrupted period, but also the indirect, latent lost value that would not have occurred. Especially, temporary job losses during a disaster period may disturb normal economic and business activities. As a result, until the damaged economy is recovered to the normal economic status, open innovations in the economy will be hindered.

Severe economic damages generated by the two hurricanes that hit the Gulf of Mexico in August 2005 were recorded costliest in the U.S. history. Before the two hurricanes of Katrina and Rita, a hurricane registered as the largest economic damages is Andrew, which recorded $\$ 30$ billion losses (National Research Council, 1999). The intensity of Hurricane Katrina that touched down the Louisiana coast was Category 3 and its continual wind speed was $130 \mathrm{mph}$; this superstorm broke the levees of New Orleans. Crescent City was devastated by the flood generated from broken levees. Katrina resulted in $80 \%$ of flood for New Orleans City and more than 1,800 casualties (Louisiana Geographic Information Center, 2005), recorded as the largest damaging natural disaster in U.S. history. Rita, after a month later, hit the Gulf of Mexico coasts and consecutively disrupted the coastal communities in Louisiana again, generating 130 fatalities (Knabb et al., 2006).

It occurred extremely high numbers of devastating floods, heavy storms, droughts, heat waves, and wildfires over the past few years in the U.S. In 2011, the Federal Emergency Management Agency (FEMA) made a record 1,814 "major disaster declarations," which enable counties damaged from extreme weather events to seek federal disaster assistance. In 2015, the agency made 854 major disaster declarations. Sandy was one of the costliest hurricanes in U.S. history (Weis and Weidman 2012). There are 613 and 702 major declarations in 2012 and 2013 such as Fig. 1. In particular, Fig. 2 shows the regional distribution of disaster declarations associated with floods such as storm, typhoon, hurricane etc. since 2000.

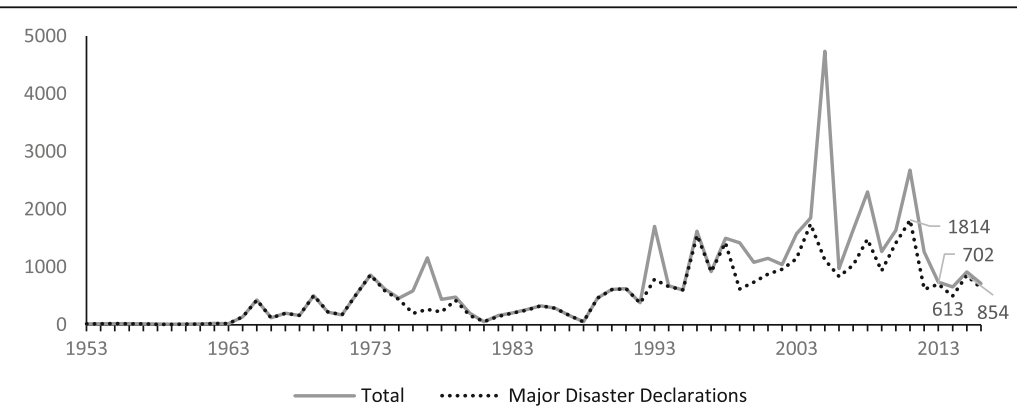

Fig. 1 Disaster Declarations by Year. Data source: FEMA(2016a) 


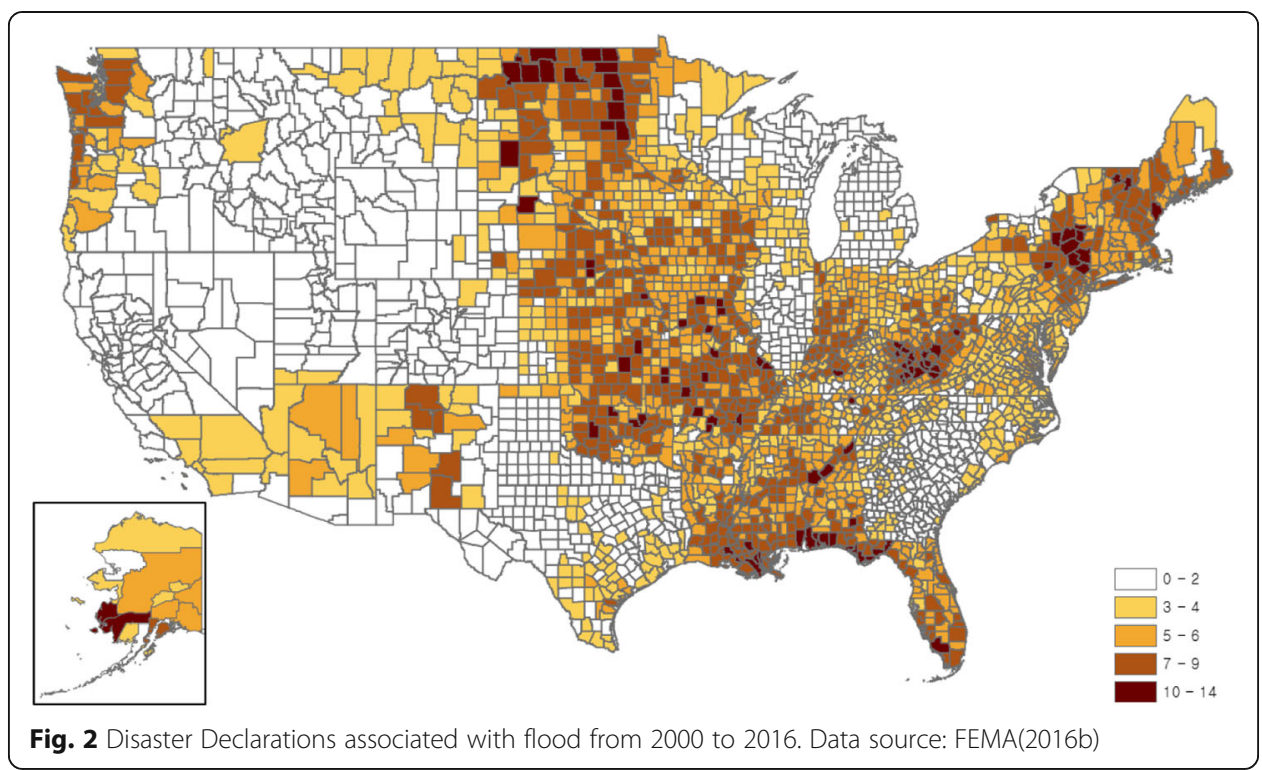

The climate change has an effect on these extreme weather events according to studies investigating disasters such as Otto et al. (2012), Stott et al. (2004), Lewis and Karoly (2013), Sippel and Otto (2014), Pall et al. (2011), and Fischer and Knutti (2015). For the effect of high-temperature, Fischer and Knutti (2015) analyzed what fraction of all globally occurring extreme weather events is relevant to the warming. Especially, debates in the coastal regions over recovery from Sandy have moved to debates over what the most appropriate means to respond climate change are. Sea level rise has emerged as, perhaps, the most significant manifestation of climate change in the Northeastern coastal areas. Revealing the evidence of recently accelerated sea level rise on the North American Atlantic coast, Sallenger et al. (2012) represented that the rate of sea level rise in the northeast critical regions were 3-4 times higher than the global average. Many of studies expect that sea level rise will continuously increase over the next several decades, and many of people will frequently be confronted with the risk of future storms from the increased storm surge associated with the sea level rise.

This hurricane-generated economic loss is, unfortunately, still being experienced in the U.S. Since the Gulf disaster, several studies on the economic impacts of Hurricanes Katrina and Rita have been reported. After that, Hurricane Sandy occurred in 2012 is recorded as one of the largest storms ever to mash American territory. The Sandycaused disruptions of metro built environments and natural environmental systems demonstrated how fragile New York City (NYC) and Long Island areas are from hurricanes and storm surges. This promptly generated a new discussion of building coastal barriers surrounding the shorelines of the areas, expecting to minimize the destructive risk from a similar event in the future. Before Sandy, the risk assessment studies for the city and its surrounding areas have been developed around the premise of a single or few flooding events. Recent studies have begun analyzing the flooding risk and its consequences more comprehensively (Aerts et al., 2013; Won et al., 2015).

An issue that was not seriously explored in recent studies is how to account for economic damages more extensively and accurately. Majority studies of estimating economic damages rely on governmental reports that mostly focus on the magnitude 
of building losses directly damaged or on speculations about future impacts on the area already damaged. For example, Holtz-Eakin (2005) estimated direct capital losses from Katrina and Rita as $\$ 70$ to $\$ 130$ billions. Narrowing down the geographical scope to Louisiana only, total losses from the both hurricanes were reported as $\$ 115$ billion by federal reimbursements received (Kent, 2006). Analyzing historical data related to the economic impacts from the U.S. hurricanes since 1950, Nordhaus (2006) quoted $\$ 81$ billion for the Katrina losses. Also, National Hurricane Center (2007) released Rita's damages as $\$ 11.3$ billion. In summary, these studies report that the economic losses stemming from the both hurricanes plausibly range $\$ 92$ to $\$ 115$ billion. Even though various estimates on the economic costs have been reported by location, type of damages, period and so on, it needs to estimate economic impacts beyond counting the simple direct losses. While some studies have attempted indirect damage assessment to use input-output (IO) models (Zandi, 2012; Kunz et al., 2013), they only used a national IO model resulting from business interruption of a specific sector and its inter-industrial linkages.

As clearly addressed by Park et al. (2013; 2014a), when considering inter-industrial and inter-regional economic connections which are becoming more complicated, accounting for the indirectly connected ripple impacts is more important in economic damage estimation. This is because technological innovations in various sectors in an economy may not be proceeded during (and quite long after) the disaster presence. As a result, supporting many mitigation and prevention policies that would reduce the economic losses and expedite technological innovations in a recovering economy should consider all possible costs caused by a disaster. This study, therefore, provides a full procedure to estimate a type of interconnected economic damages, based on the National Interstate Economic Model (NIEMO) and the temporarily lost jobs using Census data during the first 4 days caused by Hurricane Sandy. While Park et al. (2014a) analyzed a similar case, the full approach adopted in this study is critically important in the literature and applied to evaluate the economic impact urgently needed for the future disaster cases. Furthermore, an empirical application of the supply-side IO approach is another important contribution of this study as explained in The supply-side national interstate economic model.

Input data and data processing presents how this study collected and managed data needed for NIEMO. The supply-side National Interstate Economic Model provides a methodological approach of supply-side NIEMO that was applied for this study. The Results section provides the results of supply-side NIEMO analysis with various maps via geographical information systems using the input data. Finally, Conclusions provides conclusions of this study and delivers various policy implications to be considered for a similar hurricane event in the future.

\section{Input data and data processing}

Input data used for this study include various sources. Firstly, the OnTheMap data (onthemap.ces.census.gov) released by the U.S. Census Bureau are one of the main input data sources. The data source includes a web-based emergency management interface based on U.S. workforce statistics in real time. Secondly, a report of "Post-Tropical Cyclone Sandy" released by the Federal Emergency Management Agency was used to calculate direct impacts and develop scenarios. This data source is used to account for 
the unemployed number of workers for 4 days starting from October 26, 2012. Sandy hit ten states in the U.S., which declared the emergency state due to the losses of jobs and buildings. Table 1 depicts the temporarily lost jobs that were affected by Sandy during the 4 days by each state.

However, the temporarily lost jobs stemming from Sandy which was collected from OntheMap are only classified either by region or by industry type. Also, the industry type is only defined as 2-digit North American Industry Classification System (NAICS). To allocate the lost job information from OntheMap to each NAICS code per state and calculate total income losses for each impacted state by industry type, the average income data by industry sector were used as weight. The income data were collected from the Bureau of Economic Analysis (BEA). The detailed procedure of data management is described as follows.

Firstly, the detailed procedure calculating job losses by each industry type per each state for a specific date is suggested in equation (1), where some adjustments on the original data were made.

$$
Q_{i, j, t}=A W_{i, t} \times S W_{j, t}
$$

Where $Q_{i, j, t}=$ the lost jobs from Sandy by each industry per each state by date;

$i=$ affected states by Sandy;

$j=$ NAICS industry sectors (for example, $1=$ sector of Agriculture, Forestry, Fishing and Hunting, 2 =sector of Mining, Quarrying, and Oil and Gas Extraction, and so on);

$t=$ affected date (Oct. 26 to Oct. 29);

$A W=$ affected workers;

$S W=$ share of affected workers by each industry sector per each day.

Two day-by-day datasets about the affected workers from Sandy were collected from OntheMap. Because OntheMap only provides either a set of state-level information on the number of lost jobs or a set of industry-level information on the number of lost jobs that are only available for the entire region affected, it needs to combine the

Table 1 Lost jobs affected by Sandy during 4 days

\begin{tabular}{|c|c|c|c|c|c|}
\hline State & $10 / 26 / 2012$ & $10 / 27 / 2012$ & $10 / 28 / 2012$ & $10 / 29 / 2012$ & Total \\
\hline Connecticut & 0 & 0 & 0 & $1,457,513$ & $1,457,513$ \\
\hline District of Columbia & 0 & 0 & 0 & 586,058 & 586,058 \\
\hline Florida & 241,658 & 0 & 0 & 0 & 241,658 \\
\hline Maryland & 0 & 0 & 0 & $2,241,652$ & $2,241,652$ \\
\hline New Hampshire & 0 & 0 & 0 & 550,738 & 550,738 \\
\hline New Jersey & 0 & 0 & 0 & $3,447,615$ & $3,447,615$ \\
\hline New York & 0 & 0 & 0 & $6,082,541$ & $6,082,541$ \\
\hline North Carolina & 0 & 223,193 & 21,312 & $3,110,178$ & $3,354,683$ \\
\hline Pennsylvania & 0 & 0 & 0 & $3,579,837$ & $3,579,837$ \\
\hline Rhode Island & 0 & 0 & 0 & 405,423 & 405,423 \\
\hline South Carolina & 0 & 29,164 & 0 & 0 & 29,164 \\
\hline Virginia & 0 & 0 & 0 & $3,076,954$ & $3,076,954$ \\
\hline Total & 241,658 & 252,357 & 21,312 & $24,538,509$ & $25,053,836$ \\
\hline
\end{tabular}

Source: Post-Tropical Cyclone Sandy from the Federal Emergency Management Agency 
different data structure, which can return lost jobs by each industry per state. Also, using the day-by-day portion per industry from the entire region dataset, the affected workers by state per day were proportionally multiplied.

Secondly, new lost jobs from Sandy were estimated by each industry and by each state. Two industry sectors, NAICS Sector 1 that includes agriculture and NAICS Sector 2 that includes mining, do not exist in Washington D.C. To estimate the D.C.'s sector information, an approach that utilizes prevailing data in other states was applied. Consistent with the definition of nominations in equation (1), details of this process are described through equations (2) to (6).

If $j$ is Agriculture, forestry, fishing and hunting sector or Mining, Quarrying, and Oil and Gas extraction sector ( $j=1$ or 2$)$,

$$
\begin{aligned}
& \text { If } i \text { is } D C, Q_{D C, j, t}^{\prime}=0 \\
& \text { If } i \text { is not } D C, Q_{i, j, t}^{\prime}=Q_{i, j, t}+\left(S I_{i, t} \times Q_{D C, j, t}\right)
\end{aligned}
$$

If $j$ is not Agriculture, forestry, fishing and hunting sector and Mining, Quarrying, and Oil and Gas extraction sector ( $j \neq 1$ and 2 ),

$$
\begin{aligned}
& A S J_{j, t}=A W_{j, t} /\left(A W_{t}-A W_{j=1, t}-A W_{j=2, t}\right) \\
& \text { If } i \text { is } D C, Q_{D C, j, t}^{\prime}=Q_{D C, j, t}+\left\{A S j_{j, t} \times\left(Q_{D C, j=1, t}+Q_{D C, j=2, t}\right)\right\} \\
& \text { If } i \text { is not } D C, Q_{i, j, t}^{\prime}=Q_{i, j, t}-\left\{S I_{i, t} \times\left(Q_{D C, j=1, t}+Q_{D C, j=2, t}\right)\right\}
\end{aligned}
$$

where $Q_{i, j, t}^{\prime}$ indicates the adjusted $Q_{i, j, t} ;$

$$
A S J_{j, t}=\text { allocated } S J
$$

$S I=$ share of affected workers by each state and by each day

Tables 6-9 in Appendix present the estimated workers affected by Sandy by each day (October 26 to October 29).

Thirdly, the average annual personal income by industry type, which is available from BEA as suggested in Table 10 of Appendix, was used to estimate total direct income losses from Sandy. Total direct income losses by industry sector were estimated by multiplying the estimated total number of lost jobs in the second procedure with the average income per industry.

Finally, sector conversion to USC Sector system was conducted to be prepared as input data for NIEMO. Using the NAICS-USC bridge table developed by Park et al. (2007), the 2-digit NACIS code system could be transferred to the USC Sector system. For the sectoral conversion that requires more accurate matching for different sector classification systems, a weight vector was developed using the number of employment information at the national level available from IMPLAN.

Via the procedure explained in the previous paragraphs, the final data of total income losses needed as input information by USC Sector to run the supply-side NIEMO model are presented in Table 2. Total income losses per day by USC Sector, as expected, were highest on October 29 when Sandy curved west-northwest, recording about $\$ 7$ billion losses in total. Also, it was estimated the other 3 days reached about $\$ 100$ million of total income losses. In terms of total income losses by industry type, temporary jobs were dominant in the sectors related to Wholesale Trade (USC32), Coal 
Table 2 Total income losses of Hurricane Sandy by USC Sector

\begin{tabular}{|c|c|c|c|c|}
\hline \multirow[t]{2}{*}{ USC Sector } & \multicolumn{4}{|c|}{ Income losses } \\
\hline & Oct. 26 & Oct. 27 & Oct. 28 & Oct. 29 \\
\hline USC01 & -1.04 & -0.64 & -0.05 & -183.53 \\
\hline USCO2 & -1.81 & -1.14 & -0.09 & -322.24 \\
\hline USCO3 & -0.38 & -0.24 & -0.02 & -68.26 \\
\hline USCO4 & -0.04 & -0.01 & 0.00 & -5.45 \\
\hline USC05 & -0.60 & -0.35 & -0.03 & -104.37 \\
\hline USC06 & -0.01 & 0.00 & 0.00 & -1.15 \\
\hline USC07 & -0.03 & -0.02 & 0.00 & -5.07 \\
\hline USC08 & -0.11 & -0.35 & 0.00 & -150.19 \\
\hline USC09 & -0.03 & -0.10 & 0.00 & -43.76 \\
\hline USC10 & -0.36 & -1.15 & -0.01 & -486.48 \\
\hline USC11 & -0.01 & 0.00 & 0.00 & -2.01 \\
\hline USC12 & -0.03 & -0.01 & 0.00 & -4.19 \\
\hline USC13 & 0.00 & 0.00 & 0.00 & -0.55 \\
\hline USC14 & -0.03 & -0.01 & 0.00 & -4.46 \\
\hline USC15 & -0.09 & -0.02 & 0.00 & -13.04 \\
\hline USC16 & -0.23 & -0.12 & -0.01 & -39.02 \\
\hline USC17 & -0.04 & -0.01 & 0.00 & -6.65 \\
\hline USC18 & -0.27 & -0.32 & -0.02 & -52.78 \\
\hline USC19 & -0.19 & -0.08 & -0.01 & -31.00 \\
\hline USC20 & -0.05 & -0.01 & 0.00 & -7.22 \\
\hline USC21 & -0.04 & -0.01 & 0.00 & -5.67 \\
\hline USC22 & -0.11 & -0.03 & 0.00 & -16.53 \\
\hline USC23 & -0.14 & -0.03 & 0.00 & -22.13 \\
\hline USC24 & -0.35 & -0.33 & -0.02 & -65.02 \\
\hline USC25 & -0.11 & -0.03 & 0.00 & -16.82 \\
\hline USC26 & -0.04 & -0.01 & 0.00 & -6.57 \\
\hline USC27 & -0.05 & -0.01 & 0.00 & -7.78 \\
\hline USC28 & -0.06 & -0.01 & 0.00 & -9.12 \\
\hline USC29 & -0.15 & -0.07 & -0.01 & -25.48 \\
\hline USC30 & -1.50 & -3.22 & -0.18 & -196.41 \\
\hline USC31 & -2.32 & -2.79 & -0.18 & -243.26 \\
\hline USC32 & -3.55 & -3.26 & -0.21 & -735.04 \\
\hline USC33 & -0.66 & -0.62 & -0.04 & -115.73 \\
\hline USC34 & -0.37 & -0.35 & -0.02 & -64.46 \\
\hline USC35 & -0.90 & -0.65 & -0.08 & -72.20 \\
\hline USC36 & -0.68 & -1.03 & -0.06 & -145.71 \\
\hline USC37 & -1.24 & -1.12 & -0.11 & -189.27 \\
\hline USC38 & -0.03 & -0.09 & -0.02 & -18.70 \\
\hline USC39 & -7.07 & -11.13 & -0.62 & $-1,157.36$ \\
\hline USC40 & -0.18 & -0.11 & -0.01 & -53.96 \\
\hline USC41 & -2.92 & -2.58 & -0.17 & -303.85 \\
\hline USC42 & -2.22 & -4.38 & -0.35 & -342.37 \\
\hline USC43 & -3.83 & -3.89 & -0.19 & -403.39 \\
\hline
\end{tabular}


Table 2 Total income losses of Hurricane Sandy by USC Sector (Continued)

\begin{tabular}{lllll}
\hline USC44 & -3.08 & -6.01 & -0.52 & -358.55 \\
USC45 & -1.36 & -2.68 & -0.25 & -155.04 \\
USC46 & -1.42 & -0.94 & -0.15 & -243.39 \\
USC47 & -1.20 & -1.60 & -0.09 & -413.75 \\
Total & -40.92 & -51.61 & -3.53 & $-6,918.99$ \\
\hline
\end{tabular}

Unit: million dollars

Note: Negative sign indicates income losses. Sector definitions are provided in Table 5 of Appendix

and petroleum products (USC10), Professional, Scientific, and Technical services (USC39), Education Services (USC42), Health Care and Social Assistances (USC43), and Arts, Entertainment, and Recreation (USC44).

Also, total income losses are various by each state because Sandy moved from Florida State on October 26 to the north. The income losses moved to the north along with Sandy, passing South Carolina and North Carolina by October 28. On October 29, the income losses occurred in various Northeastern states including Connecticut, Washington, D.C., Maryland, New Hampshire, New Jersey, New York, Pennsylvania, Rhode Island, and Virginia as well as North Carolina. The detailed total income losses of each state by USC Sector are presented in Table 11 of Appendix.

\section{The supply-side National Interstate Economic Model}

Based on the total income loss dataset available in Table 11 of Appendix, the National Interstate Economic Model (NIEMO) constructed by Park et al. (2007, 2009, 2013; 2011) was applied for the total impact analysis stemming from Sandy. NIEMO is a standard type of multiregional input-output model (MRIO) which is spatially disaggregated in the U.S. As of now, NIEMO is reported as the only operational MRIO model in the U.S. while there had been trials to make an operational U.S. version MRIO. An MRIO model generically requires two datasets: trade among regions and inter-industry relations within a region. NIEMO was similarly constructed by two external datasets of Commodity Flow Survey (CFS) and state level input-output accounts available from IMPLAN (Miller and Blair, 2009: 371-372). Modifying using advanced technologies completing CFS by Park et al. (2009), NIEMO defined a new sector system with 47 economic sectors that consist of 29 commodity sectors and 18 service sectors defined as "USC Sector" and is composed of 50 states and D.C. Various applications on natural disasters are found in Richardson et al. (2014). The basic model development process and the explanation of the USC Sector system for the NIEMO presented in Fig. 3 and Table 5 of Appendix (Park \& Park, 2016), respectively.

For this study, the supply-side NIEMO model was applied because income component is part of the value-added information, not final demand information. A detailed theoretical discussion is found by Park (2008) and Park et al. (2017), and the description and the application of supply-side NIEMO are represented in the studies conducted by Park and Richardson (2014) and Richardson et al. (2014). In terms of empirical application, Park et al. (2014b) suggested the usefulness of the supply-side approach instead of using a price-type IO model if external costs cannot be normalized with total outputs.

A supply-side NIEMO permits relaxation of the fixed production coefficients assumption. Various empirical applications and elaboration of the supply-side NIEMO 


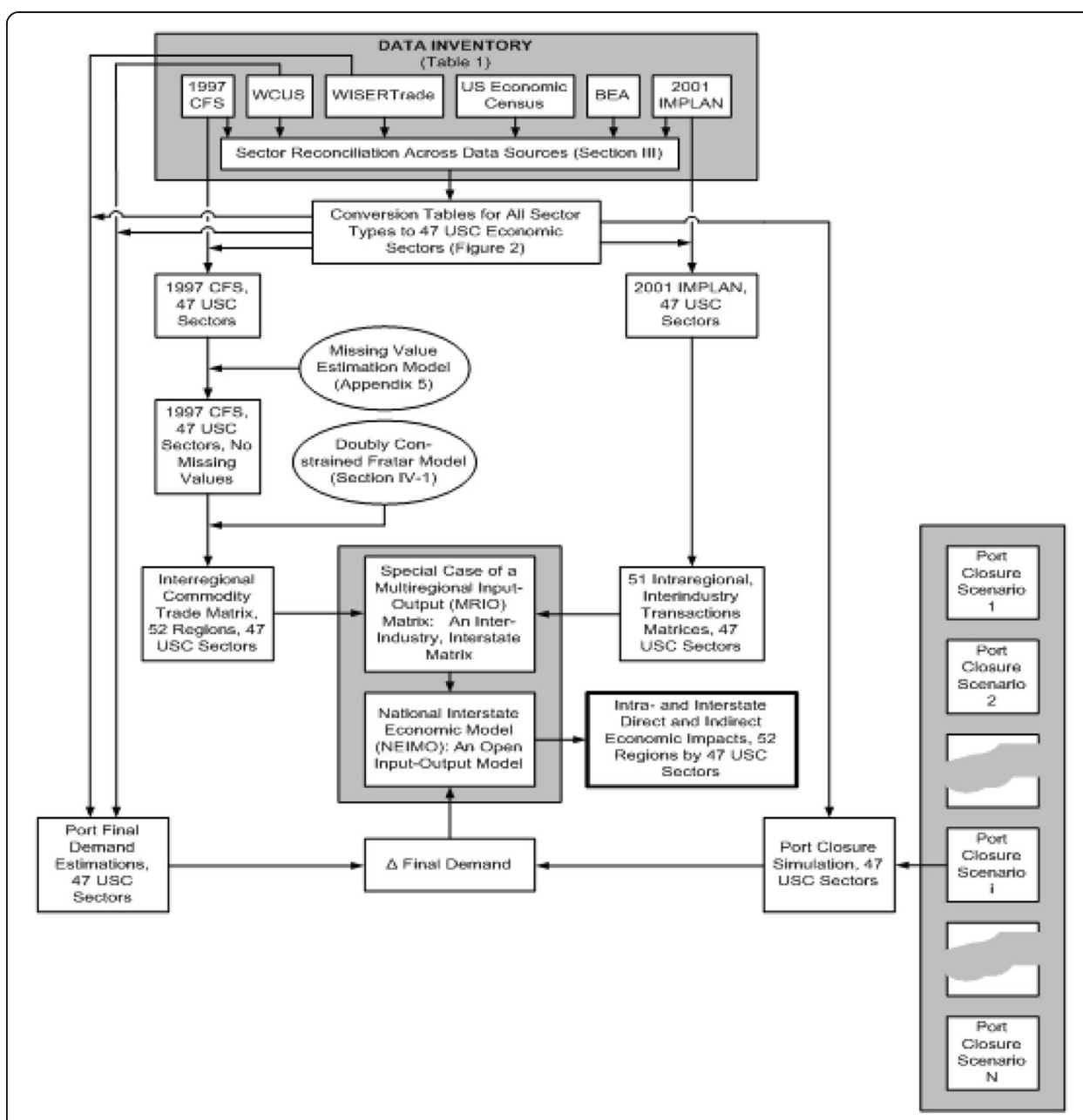

Fig. 3 NIEMO Modeling and Development Process (Park, 2008)

were conducted since a decade prior (Park, 2007; 2008; Park et al., 2008; Park et al., 2014b). The structure of the supply-side NIEMO model is suggested in equation (7) as a matrix form:

$$
\mathrm{Q}^{\mathrm{I}}=\mathrm{L}(\mathrm{I}-\mathrm{DT})^{-1}
$$

where $\mathrm{Q}^{\mathrm{I}}=$ the total input vector for 47 USC sectors and 52 regions;

$\mathrm{L}=\mathrm{a}$ vector of region specific total income losses;

$\mathrm{I}=$ identity matrix;

$\mathrm{D}=\left(\hat{Q}^{d}\right)^{-1} \mathrm{~A}$ and $\left(\hat{Q}^{d}\right)$ is the block diagonal matrix of vector $\mathrm{Q}^{\mathrm{d}}$;

$\mathrm{Q}^{\mathrm{d}}=$ the total output column vector;

$\mathrm{A}=$ the block diagonal matrix of direct technical flows among industries; and

$\mathrm{T}=$ the block diagonal matrix of interregional trade flows.

\section{Results}

Total economic impacts rippled from total income losses resulted from the lost jobs for 4 days by Sandy on the U.S. national economy were estimated via the supply-side 
NIEMO model. These impact results for the 4 days by state are suggested in Table 3 . Note that "direct impact" refers to the total income losses experienced in each USC sector by each state from Sandy, and hence, represents the total income losses aggregated to each state in the table. Also, note that "indirect impact" indicates economic impacts generated due to inter-industry and interstate linkages in NIEMO. The indirect impacts in Table 3 were aggregated to each state via inverse coefficients of supply-side NIEMO. Total impact column is the sum of direct and indirect impacts. Type I multiplier explains total economic impacts about direct impacts. While no Type II multiplier measures induced impacts in this study, this missing of Type II multiplier may decrease the economic impact amount because Sandy resulted in the closure of numerous retail stores and consumer facilities in spite that the closures were temporary. The current version of NIEMO did not include the Type II analysis components in the model itself, and analysis of final demand connections is the area of demand-side NIEMO application, not the supply-side.

Based on the reduction of total income during the 4 days by $\$ 7$ billion, the top three states that are most economically impacted were found. New York State was the most impacted state, recording $\$ 2.8$ billion in total. New Jersey ranked the second impacted state, recording about a half of New York damages. Both states of New York and New Jersey are located in Northeastern region of the U.S. and were seriously damaged on October 29. Note that North Carolina ranked the third impacted state but experienced 3 day job losses, recording about $\$ 1$ billion economic impacts. In total, the supply-side NIEMO generated additional $\$ 3$ billion indirect losses from the income losses for the 4 days, and hence, the Type I multiplier is 1.48. This indicates that Sandy's economic impacts on the U.S. per day associated with temporary income losses would be $\$ 2.5$ billion on average.

Also, based on the supply-side NIEMO results, patterns of how the economic impacts of the top three USC sectors are distributed to whole states of the U.S. were depicted in Fig. 4. The top three sectors include Professional services related (USC39), Wholesale (USC32) and Health Care and Social Assistances (USC43), of which the total economic losses are $\$ 1.3$ billion, $\$ 0.9$ billion, and $\$ 0.7$ billion, respectively. It is another finding that the geographical impacts are different among the three top sectors. The most impacted industry, Professional Services (USC39), is more concentrated in the Northeastern region, while the economic impacts of the other two industries are rather spread out to the whole country.

It is also valuable to compare the current results with other studies to understand how reliable the economic impacts estimated in this study are. While it is very limited to find Sandy-generated economic impact studies, Mantell et al. (2013) reported a result of Sandy's impact on New Jersey State only. Even though the results in the report counted only for the fourth quarter of 2012, focusing on October 29 and most damages occurred in New Jersey, the results in the report provide a useful comparison to the results of this study. This is because this study includes the same areal boundary and date as in the New Jersey report. By applying a different model, which is R/ECON developed from the Bloustein School of Public Policy at Rutgers University, the Bloustein School team measured total direct impacts at $\$ 1.2$ billion. When comparing the result with the direct loss estimate using temporary income losses for a shorter time period which was reported as $\$ 1$ billion losses, we can understand the reliability of this approach to estimating the direct impacts, and in turn, the total impacts via NIEMO. 
Table 3 Total economic impacts by state stemming from income losses by Hurricane Sandy

\begin{tabular}{|c|c|c|c|}
\hline State & Direct impact & Indirect impact & Total impact \\
\hline$\overline{\mathrm{AL}}$ & 0.0000 & -7.6019 & -7.6019 \\
\hline AK & 0.0000 & -1.2517 & -1.2517 \\
\hline$A Z$ & 0.0000 & -5.5135 & -5.5135 \\
\hline AR & 0.0000 & -3.6420 & -3.6420 \\
\hline$C A$ & 0.0000 & -49.1253 & -49.1253 \\
\hline $\mathrm{CO}$ & 0.0000 & -7.0589 & -7.0589 \\
\hline CT & -500.8351 & -199.5441 & -700.3792 \\
\hline DE & 0.0000 & -5.1775 & -5.1775 \\
\hline DC & -268.9149 & -87.5501 & -356.4650 \\
\hline $\mathrm{FL}$ & -40.9229 & -43.6025 & -84.5254 \\
\hline GA & 0.0000 & -16.1538 & -16.1538 \\
\hline $\mathrm{HI}$ & 0.0000 & -2.0611 & -2.0611 \\
\hline ID & 0.0000 & -1.4826 & -1.4826 \\
\hline IL & 0.0000 & -23.7699 & -23.7699 \\
\hline IN & 0.0000 & -10.3701 & -10.3701 \\
\hline IA & 0.0000 & -5.8395 & -5.8395 \\
\hline KS & 0.0000 & -4.6823 & -4.6823 \\
\hline KY & 0.0000 & -6.2082 & -6.2082 \\
\hline LA & 0.0000 & -5.9758 & -5.9758 \\
\hline ME & 0.0000 & -4.6431 & -4.6431 \\
\hline$M D$ & -641.7710 & -280.8488 & -922.6198 \\
\hline MA & 0.0000 & -30.8259 & -30.8259 \\
\hline $\mathrm{Ml}$ & 0.0000 & -18.8088 & -18.8088 \\
\hline $\mathrm{MN}$ & 0.0000 & -7.5224 & -7.5224 \\
\hline MS & 0.0000 & -3.7559 & -3.7559 \\
\hline $\mathrm{MO}$ & 0.0000 & -8.3069 & -8.3069 \\
\hline MT & 0.0000 & -1.2149 & -1.2149 \\
\hline NE & 0.0000 & -3.0994 & -3.0994 \\
\hline NV & 0.0000 & -2.1973 & -2.1973 \\
\hline $\mathrm{NH}$ & -135.6202 & -53.9827 & -189.6029 \\
\hline NJ & $-1,084.0073$ & -448.6113 & $-1,532.6186$ \\
\hline NM & 0.0000 & -2.0005 & -2.0005 \\
\hline NY & $-1,987.5464$ & -808.4490 & $-2,795.9954$ \\
\hline NC & -790.6532 & -332.1289 & $-1,122.7822$ \\
\hline ND & 0.0000 & -1.1363 & -1.1363 \\
\hline $\mathrm{OH}$ & 0.0000 & -28.6345 & -28.6345 \\
\hline OK & 0.0000 & -4.8809 & -4.8809 \\
\hline OR & 0.0000 & -3.9606 & -3.9606 \\
\hline PA & -771.1960 & -336.8265 & $-1,108.0225$ \\
\hline $\mathrm{Rl}$ & -127.5603 & -49.7850 & -177.3453 \\
\hline SC & -5.5351 & -13.8146 & -19.3498 \\
\hline SD & 0.0000 & -1.3279 & -1.3279 \\
\hline $\mathrm{TN}$ & 0.0000 & -10.6721 & -10.6721 \\
\hline TX & 0.0000 & -34.5049 & -34.5049 \\
\hline
\end{tabular}


Table 3 Total economic impacts by state stemming from income losses by Hurricane Sandy (Continued)

\begin{tabular}{llll}
\hline UT & 0.0000 & -2.3815 & -2.3815 \\
VM & 0.0000 & -3.6914 & -3.6914 \\
VA & -660.4797 & -240.9923 & -901.4720 \\
WA & 0.0000 & -8.3913 & -8.3913 \\
WW & 0.0000 & -5.5352 & -5.5352 \\
WI & 0.0000 & -10.3925 & -10.3925 \\
WY & 0.0000 & -0.8241 & -0.8241 \\
US Total & $-7,015.04$ & $-3,250.76$ & $-10,265.80$ \\
Rest of World & 0.00 & -113.8617 & -113.8617 \\
World Total & $-7,015.04$ & $-3,364.62$ & $-10,379.66$ \\
Type I Multiplier & & & 1.48 \\
\hline
\end{tabular}

Units: million dollars; Note: Negative sign indicates economic losses

It has been more than 4 years since Sandy made landfall in October 2012, impacting on East Coast of the U.S. Several post-storm assessments have been made by various organizations in the wake of Sandy to provide recovery support (de Moel et al., 2013). As found in Table 4, New Jersey and New York have been provided the federal relief fund. New York State, as a single state, has received federal assistance over \$13.6 billion in total through Individual Assistance grants, Small Business Administration (SBA) lowinterest disaster loans, National Flood Insurance Program payments and Public Assistance grants. These account for about $82 \%$ of total Sandy Recovery support. Details of the support are followed.

First of all, FEMA referred 211,970 households to the Individuals and Households Program. Through the program, more than $\$ 1$ billion were disbursed to survivors, of which nearly $\$ 865$ million was for housing assistance. Also, nearly 5,600 survivors received more than $\$ 8.9$ million through disaster unemployment assistance. Secondly, the SBA has approved 23,216 individuals and businesses for its disaster loans. The total loan amount reaches $\$ 1.5$ billion: $\$ 1.3$ billion of the total loan were approved for homeowners and renters while $\$ 267.5$ million for businesses. Thirdly, more than $\$ 3.9$ billion in flood insurance payments made to 57,244 policyholders. Fourthly, more than $\$ 5.5$ billion through FEMA Public Assistance grants was obligated to communities and some nonprofit organizations, supporting projects needed to protect against future disaster damages by over $\$ 1.7$ billion. Finally, the FEMA Hazard Mitigation Grant Program has obligated $\$ 84.7$ million of funding to 24 sub-applicants conducted for New York State priority hazard mitigation projects (FEMA, 2016d). However, all of the recovery support is less than the twice of the total impacts estimated for only 4 days.

\section{Conclusions}

A Federal Flood Insurance law passed in July of 2012 before Sandy occurrence, which dramatically increased both premiums and rebuilding costs, as well as the lag in offering mold treatments especially for low income households (Park et al., 2014a). According to a report on quick economic facts from Sandy released in 2013 (1 Year After Superstorm Sandy: Quick Economic Facts, 2013), total losses insured were 


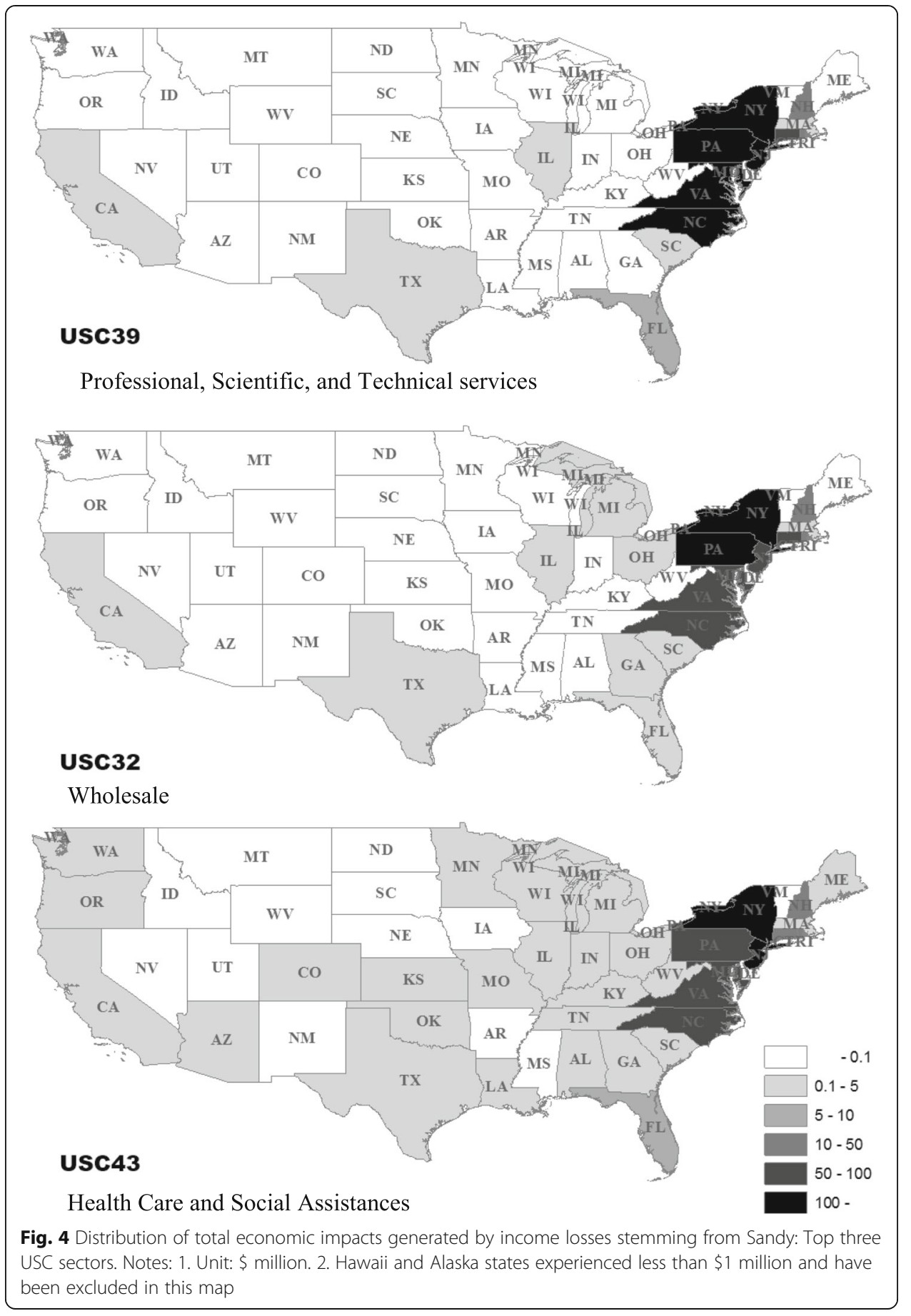

Table 4 Sandy recovery

\begin{tabular}{ll}
\hline Assistance type & Amount \\
\hline Assistance to disaster survivors (Individual Assistance) & $\$ 1.4$ billion \\
Assistance to state, local and tribal governments (Public Assistance) & $\$ 14.2$ billion \\
Hazard Mitigation grants & $\$ 822$ million \\
\hline
\end{tabular}

Note: Amount represents FEMA funding in New Jersey and New York combined Source: FEMA(2016c) 
estimated by approximately $\$ 26$ billion. Private insurance companies accounted for three quarters of the total by paying out through auto, homeowners and business insurance claims by $\$ 18.75$ billion in total. The rest of the claims, $\$ 7.1$ billion, were covered by the National Flood Insurance Program. Considering only for the insured amount in the U.S., Sandy is the third costliest natural catastrophe. According to private insurance company loss amount, Hurricanes Katrina and Andrew ranked top one and two natural disasters, recording $\$ 48.7$ billion and $\$ 25.6$ billion, respectively. However, the insurance payouts do not account for temporary labor inactivity in business and miss to consider either its inter-industrial impacts or inter-regional connections, resulting in less economic damages.

In this aspect, this study analyzed how the U.S. and state economies could be impacted by the short-term job losses generated by Sandy and during its path to the North from Florida to New Hampshire. Since both Katrina and Rita in 2012, Sandy brought another tragedy to the Northeastern region of the U.S. including New York City, where $\$ 2.8$ billion of total economic impacts occurred on the 4 days. However, 99\% of the total economic losses only occurred in the last day of Sandy's attack. Furthermore, $\$ 10$ billion losses of the nation-wide impacts attained by the NIEMO's inter-industrial and inter-regional economic model include $\$ 3$ billion of latent, indirect economic losses in the U.S. which must have been accounted for preventing future hurricane damages.

However, this study does not include physical losses and its latent impacts via the economic relations through NIEMO. As Park et al. (2014a) introduced a conceptual approach that accounts for physical disruptions and environmental damages, the way of combining HAZUS with NIEMO can capture Sandy's impacts stemming from the physical disruptions on businesses and residential occupancies. Especially, the HAZUSNIEMO approach can contribute to accounting for resilient paths of the lost business production due to the short-term job losses during Sandy's landfall, and hence, to delivering discussions on economic effects of various mitigation and prevention policies already implemented.

Disaster recovery is important in economic innovations. The recovery path is as much needed to build the future stronger as to repair past damages, because economic innovations usually appear in the normal market fully recovered from a disaster. While FEMA keeps continuing to collaborate with local, state and other federal partners, supporting the recovery of individuals, families, businesses and communities from the superstorm begins from the economic damage assessment measured as accurately as we can. Even though various simulation results to be conducted and measured by HAZUS-NIEMO can advance our understanding of future hurricane impacts, the temporary income-loss approach applied in this study has its novelty especially in addressing short-term labor losses and understanding of economic disruptions that hinder innovations. Therefore, by adding the HAZUS-NIEMO that provides long-term strategies for the effectiveness of hurricane policies to this type of a short impact study, various adaptation and resilience efforts in reducing the economic losses after a hurricane can be more precise.

Still, this result may have a limitation to be directly applied to all other cases. However, note that the approach applied here is not constrained to the Sandy case of the U.S.; rather, the analytical way to measure disaster impacts applied in this study can 
provide a valuable experience to other mega cities such as Seoul, Tokyo, Beijing and so on because of their high population and employment density level. Therefore, unless unexpected natural disasters can be avoided, local, state and federal planners and policymakers must help residents and businesses recover from the disasters more quickly by providing more accurate damage information as this study conducted. By doing so, a city will eventually enhance market innovations, quickly boosting resilience against a natural disaster.

\section{Appendix}

Table 5 Definitions for the NIEMO's USC Sector system

\begin{tabular}{|c|c|}
\hline Sector & Description \\
\hline USC01 & Live animals and live fish \& Meat, fish, seafood, and their preparations \\
\hline USC02 & Cereal grains \& Other agricultural products except for Animal Feed \\
\hline USC03 & Animal feed and products of animal origin, n.e.c. \\
\hline USC04 & Milled grain products and preparations, and bakery products \\
\hline USC05 & Other prepared foodstuffs and fats and oils \\
\hline USC06 & Alcoholic beverages \\
\hline USC07 & Tobacco products \\
\hline USC08 & Nonmetallic minerals (Monumental or building stone, Natural sands, Gravel and crushed stone, n.e.c.) \\
\hline USC09 & Metallic ores and concentrates \\
\hline USC10 & Coal and petroleum products (Coal and Fuel oils, n.e.c.) \\
\hline USC11 & Basic chemicals \\
\hline USC12 & Pharmaceutical products \\
\hline USC13 & Fertilizers \\
\hline USC14 & Chemical products and preparations, n.e.c. \\
\hline USC15 & Plastics and rubber \\
\hline USC16 & Logs and other wood in the rough \& Wood products \\
\hline USC17 & Pulp, newsprint, paper, and paperboard \& Paper or paperboard articles \\
\hline USC18 & Printed products \\
\hline USC19 & Textiles, leather, and articles of textiles or leather \\
\hline USC20 & Nonmetallic mineral products \\
\hline USC21 & Base metal in primary or semi-finished forms and in finished basic shapes \\
\hline USC22 & Articles of base metal \\
\hline USC23 & Machinery \\
\hline USC24 & Electronic and other electrical equipment and components, and office equipment \\
\hline USC25 & Motorized and other vehicles (including parts) \\
\hline USC26 & Transportation equipment, n.e.c. \\
\hline USC27 & Precision instruments and apparatus \\
\hline USC28 & Furniture, mattresses and mattress supports, lamps, lighting fittings, and illuminated signs \\
\hline USC29 & Miscellaneous manufactured products, Scrap, Mixed freight, and Commodity unknown \\
\hline USC30 & Utility \\
\hline USC31 & Construction \\
\hline USC32 & Wholesale Trade \\
\hline USC33 & Transportation \\
\hline
\end{tabular}


Table 5 Definitions for the NIEMO's USC Sector system (Continued)

\begin{tabular}{ll}
\hline USC34 & Postal and Warehousing \\
USC35 & Retail Trade \\
USC36 & Broadcasting and information services \\
USC37 & Finance and Insurance \\
USC38 & Real estate and rental and leasing \\
USC39 & Professional, Scientific, and Technical services \\
USC40 & Management of companies and enterprises \\
USC41 & Administrative support and waste management \\
USC42 & Education Services \\
USC43 & Health Care and Social Assistances \\
USC44 & Arts, Entertainment, and Recreation \\
USC45 & Accommodation and Food services \\
USC46 & Public administration \\
USC47 & Other services except public administration \\
\hline
\end{tabular}

Source: Park and Park (2016)

Table 6 Workers by NAICS Industry Sector at Oct. 26, 2013

\begin{tabular}{|c|c|c|c|c|c|c|c|c|c|c|c|c|c|}
\hline NAICS Industry Sector & $\mathrm{CT}$ & DC & $\mathrm{FL}$ & MD & $\mathrm{NH}$ & NJ & NY & NC & PA & $\mathrm{Rl}$ & SC & VA & Total \\
\hline Agriculture, Forestry, Fishing and Hunting & 0 & 0 & 3,146 & 0 & 0 & 0 & 0 & 0 & 0 & 0 & 0 & 0 & 3,146 \\
\hline $\begin{array}{l}\text { Mining, Quarrying, and Oil and Gas } \\
\text { Extraction }\end{array}$ & 0 & 0 & 21 & 0 & 0 & 0 & 0 & 0 & 0 & 0 & 0 & 0 & 21 \\
\hline Utilities & 0 & 0 & 1,671 & 0 & 0 & 0 & 0 & 0 & 0 & 0 & 0 & 0 & 1,671 \\
\hline Construction & 0 & 0 & 10,814 & 0 & 0 & 0 & 0 & 0 & 0 & 0 & 0 & 0 & 10,814 \\
\hline Manufacturing & 0 & 0 & 22,509 & 0 & 0 & 0 & 0 & 0 & 0 & 0 & 0 & 0 & 22,509 \\
\hline Wholesale Trade & 0 & 0 & 6,424 & 0 & 0 & 0 & 0 & 0 & 0 & 0 & 0 & 0 & 6,424 \\
\hline etail Trade & 0 & 0 & 26,250 & 0 & 0 & 0 & 0 & 0 & 0 & 0 & 0 & 0 & 26,250 \\
\hline Transportation and Warehousing & 0 & 0 & 3,305 & 0 & 0 & 0 & 0 & 0 & 0 & 0 & 0 & 0 & 3,305 \\
\hline Information & 0 & 0 & 2,720 & 0 & 0 & 0 & 0 & 0 & 0 & 0 & 0 & 0 & 2,720 \\
\hline Finance and Insurance & 0 & 0 & 7,269 & 0 & 0 & 0 & 0 & 0 & 0 & 0 & 0 & 0 & 7,269 \\
\hline Real Estate and Rental and Leasing & 0 & 0 & 3,938 & 0 & 0 & 0 & 0 & 0 & 0 & 0 & 0 & 0 & 3,938 \\
\hline $\begin{array}{l}\text { Professional, Scientific, and Technical } \\
\text { Services }\end{array}$ & 0 & 0 & 13,755 & 0 & 0 & 0 & 0 & 0 & 0 & 0 & 0 & 0 & 13,755 \\
\hline $\begin{array}{l}\text { Management of Companies and } \\
\text { Enterprises }\end{array}$ & 0 & 0 & 1,660 & 0 & 0 & 0 & 0 & 0 & 0 & 0 & 0 & 0 & 1,660 \\
\hline $\begin{array}{l}\text { Administration \& Support, Waste } \\
\text { Management and Remediation }\end{array}$ & 0 & 0 & 22,553 & 0 & 0 & 0 & 0 & 0 & 0 & 0 & 0 & 0 & 22,553 \\
\hline Educational Services & 0 & 0 & 24,127 & 0 & 0 & 0 & 0 & 0 & 0 & 0 & 0 & 0 & 24,127 \\
\hline Health Care and Social Assistance & 0 & 0 & 39,475 & 0 & 0 & 0 & 0 & 0 & 0 & 0 & 0 & 0 & 39,475 \\
\hline Arts, Entertainment, and Recreation & 0 & 0 & 5,258 & 0 & 0 & 0 & 0 & 0 & 0 & 0 & 0 & 0 & 5,258 \\
\hline Accommodation and Food Services & 0 & 0 & 22,194 & 0 & 0 & 0 & 0 & 0 & 0 & 0 & 0 & 0 & 22,194 \\
\hline Other Services & 0 & 0 & 7,431 & 0 & 0 & 0 & 0 & 0 & 0 & 0 & 0 & 0 & 7,431 \\
\hline Public Administration & 0 & 0 & 17,138 & 0 & 0 & 0 & 0 & 0 & 0 & 0 & 0 & 0 & 17,138 \\
\hline Total & 0 & 0 & 241,658 & 0 & 0 & 0 & 0 & 0 & 0 & 0 & 0 & 0 & 241,658 \\
\hline
\end{tabular}


Table 7 Workers by NAICS Industry Sector at Oct. 27, 2013

\begin{tabular}{|c|c|c|c|c|c|c|c|c|c|c|c|c|c|}
\hline NAICS industry sector & $C T$ & DC & $\mathrm{FL}$ & MD & $\mathrm{NH}$ & NJ & NY & NC & PA & $\mathrm{Rl}$ & SC & VA & Total \\
\hline Agriculture, Forestry, Fishing and Hunting & 0 & 0 & 0 & 0 & 0 & 0 & 0 & 1,166 & 0 & 0 & 152 & 0 & 1,318 \\
\hline Mining, Quarrying, and Oil and Gas Extraction & 0 & 0 & 0 & 0 & 0 & 0 & 0 & 99 & 0 & 0 & 13 & 0 & 112 \\
\hline Utilities & 0 & 0 & 0 & 0 & 0 & 0 & 0 & 1,643 & 0 & 0 & 215 & 0 & 1,858 \\
\hline Construction & 0 & 0 & 0 & 0 & 0 & 0 & 0 & 12,540 & 0 & 0 & 1,639 & 0 & 14,179 \\
\hline Manufacturing & 0 & 0 & 0 & 0 & 0 & 0 & 0 & 11,624 & 0 & 0 & 1,519 & 0 & 13,143 \\
\hline Wholesale Trade & 0 & 0 & 0 & 0 & 0 & 0 & 0 & 6,675 & 0 & 0 & 872 & 0 & 7,547 \\
\hline Retail Trade & 0 & 0 & 0 & 0 & 0 & 0 & 0 & 34,718 & 0 & 0 & 4,537 & 0 & 39,255 \\
\hline Transportation and Warehousing & 0 & 0 & 0 & 0 & 0 & 0 & 0 & 3,875 & 0 & 0 & 506 & 0 & 4,381 \\
\hline Information & 0 & 0 & 0 & 0 & 0 & 0 & 0 & 3,746 & 0 & 0 & 489 & 0 & 4,235 \\
\hline Finance and Insurance & 0 & 0 & 0 & 0 & 0 & 0 & 0 & 4,802 & 0 & 0 & 627 & 0 & 5,429 \\
\hline Real Estate and Rental and Leasing & 0 & 0 & 0 & 0 & 0 & 0 & 0 & 6,627 & 0 & 0 & 866 & 0 & 7,493 \\
\hline Professional, Scientific, and Technical Services & 0 & 0 & 0 & 0 & 0 & 0 & 0 & 11,519 & 0 & 0 & 1,505 & 0 & 13,024 \\
\hline Management of Companies and Enterprises & 0 & 0 & 0 & 0 & 0 & 0 & 0 & 1,113 & 0 & 0 & 145 & 0 & 1,258 \\
\hline $\begin{array}{l}\text { Administration \& Support, Waste Management and } \\
\text { Remediation }\end{array}$ & 0 & 0 & 0 & 0 & 0 & 0 & 0 & 12,339 & 0 & 0 & 1,612 & 0 & 13,951 \\
\hline Educational Services & 0 & 0 & 0 & 0 & 0 & 0 & 0 & 20,216 & 0 & 0 & 2,642 & 0 & 22,858 \\
\hline Health Care and Social Assistance & 0 & 0 & 0 & 0 & 0 & 0 & 0 & 30,354 & 0 & 0 & 3,966 & 0 & 34,320 \\
\hline Arts, Entertainment, and Recreation & 0 & 0 & 0 & 0 & 0 & 0 & 0 & 5,351 & 0 & 0 & 699 & 0 & 6,050 \\
\hline Accommodation and Food Services & 0 & 0 & 0 & 0 & 0 & 0 & 0 & 38,156 & 0 & 0 & 4,986 & 0 & 43,142 \\
\hline Other Services & 0 & 0 & 0 & 0 & 0 & 0 & 0 & 5,935 & 0 & 0 & 776 & 0 & 6,711 \\
\hline Public Administration & 0 & 0 & 0 & 0 & 0 & 0 & 0 & 10,695 & 0 & 0 & 1,398 & 0 & 12,093 \\
\hline Total & 0 & 0 & 0 & 0 & 0 & 0 & 0 & 223,193 & 0 & 0 & 29,164 & 0 & 252,357 \\
\hline
\end{tabular}

Table 8 Workers by NAICS Industry Sector at Oct. 28, 2013

\begin{tabular}{|c|c|c|c|c|c|c|c|c|c|c|c|c|c|}
\hline NAICS industry sector & $C T$ & DC & $\mathrm{FL}$ & $\mathrm{MD}$ & $\mathrm{NH}$ & NJ & NY & NC & $\mathrm{PA}$ & $\mathrm{Rl}$ & SC & VA & Total \\
\hline Agriculture, Forestry, Fishing and Hunting & 0 & 0 & 0 & 0 & 0 & 0 & 0 & 99 & 0 & 0 & 0 & 0 & 99 \\
\hline Mining, Quarrying, and Oil and Gas Extraction & 0 & 0 & 0 & 0 & 0 & 0 & 0 & 1 & 0 & 0 & 0 & 0 & 1 \\
\hline Utilities & 0 & 0 & 0 & 0 & 0 & 0 & 0 & 95 & 0 & 0 & 0 & 0 & 95 \\
\hline Construction & 0 & 0 & 0 & 0 & 0 & 0 & 0 & 937 & 0 & 0 & 0 & 0 & 937 \\
\hline Manufacturing & 0 & 0 & 0 & 0 & 0 & 0 & 0 & 754 & 0 & 0 & 0 & 0 & 754 \\
\hline Wholesale Trade & 0 & 0 & 0 & 0 & 0 & 0 & 0 & 485 & 0 & 0 & 0 & 0 & 485 \\
\hline Retail Trade & 0 & 0 & 0 & 0 & 0 & 0 & 0 & 4,900 & 0 & 0 & 0 & 0 & 4,900 \\
\hline Transportation and Warehousing & 0 & 0 & 0 & 0 & 0 & 0 & 0 & 299 & 0 & 0 & 0 & 0 & 299 \\
\hline Information & 0 & 0 & 0 & 0 & 0 & 0 & 0 & 268 & 0 & 0 & 0 & 0 & 268 \\
\hline Finance and Insurance & 0 & 0 & 0 & 0 & 0 & 0 & 0 & 524 & 0 & 0 & 0 & 0 & 524 \\
\hline Real Estate and Rental and Leasing & 0 & 0 & 0 & 0 & 0 & 0 & 0 & 1,483 & 0 & 0 & 0 & 0 & 1,483 \\
\hline Professional, Scientific, and Technical Services & 0 & 0 & 0 & 0 & 0 & 0 & 0 & 731 & 0 & 0 & 0 & 0 & 731 \\
\hline Management of Companies and Enterprises & 0 & 0 & 0 & 0 & 0 & 0 & 0 & 126 & 0 & 0 & 0 & 0 & 126 \\
\hline $\begin{array}{l}\text { Administration \& Support, Waste Management and } \\
\text { Remediation }\end{array}$ & 0 & 0 & 0 & 0 & 0 & 0 & 0 & 912 & 0 & 0 & 0 & 0 & 912 \\
\hline Educational Services & 0 & 0 & 0 & 0 & 0 & 0 & 0 & 1,805 & 0 & 0 & 0 & 0 & 1,805 \\
\hline Health Care and Social Assistance & 0 & 0 & 0 & 0 & 0 & 0 & 0 & 1,084 & 0 & 0 & 0 & 0 & 1,084 \\
\hline Arts, Entertainment, and Recreation & 0 & 0 & 0 & 0 & 0 & 0 & 0 & 524 & 0 & 0 & 0 & 0 & 524 \\
\hline Accommodation and Food Services & 0 & 0 & 0 & 0 & 0 & 0 & 0 & 3,866 & 0 & 0 & 0 & 0 & 3,866 \\
\hline Other Services & 0 & 0 & 0 & 0 & 0 & 0 & 0 & 581 & 0 & 0 & 0 & 0 & 581 \\
\hline Public Administration & 0 & 0 & 0 & 0 & 0 & 0 & 0 & 1,838 & 0 & 0 & 0 & 0 & 1,838 \\
\hline Total & 0 & 0 & 0 & 0 & 0 & 0 & 0 & 21,312 & 0 & 0 & 0 & 0 & 21,312 \\
\hline
\end{tabular}




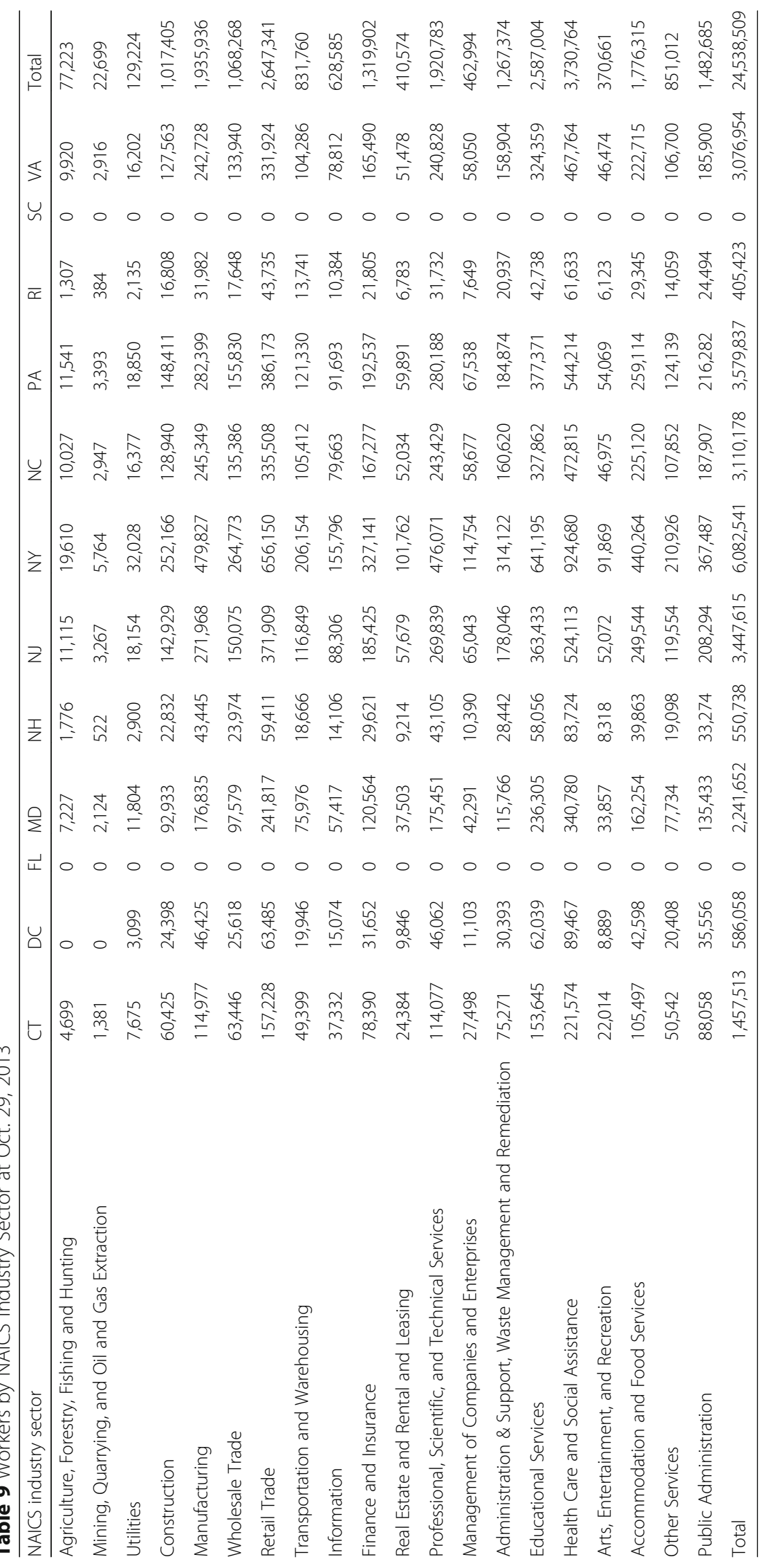




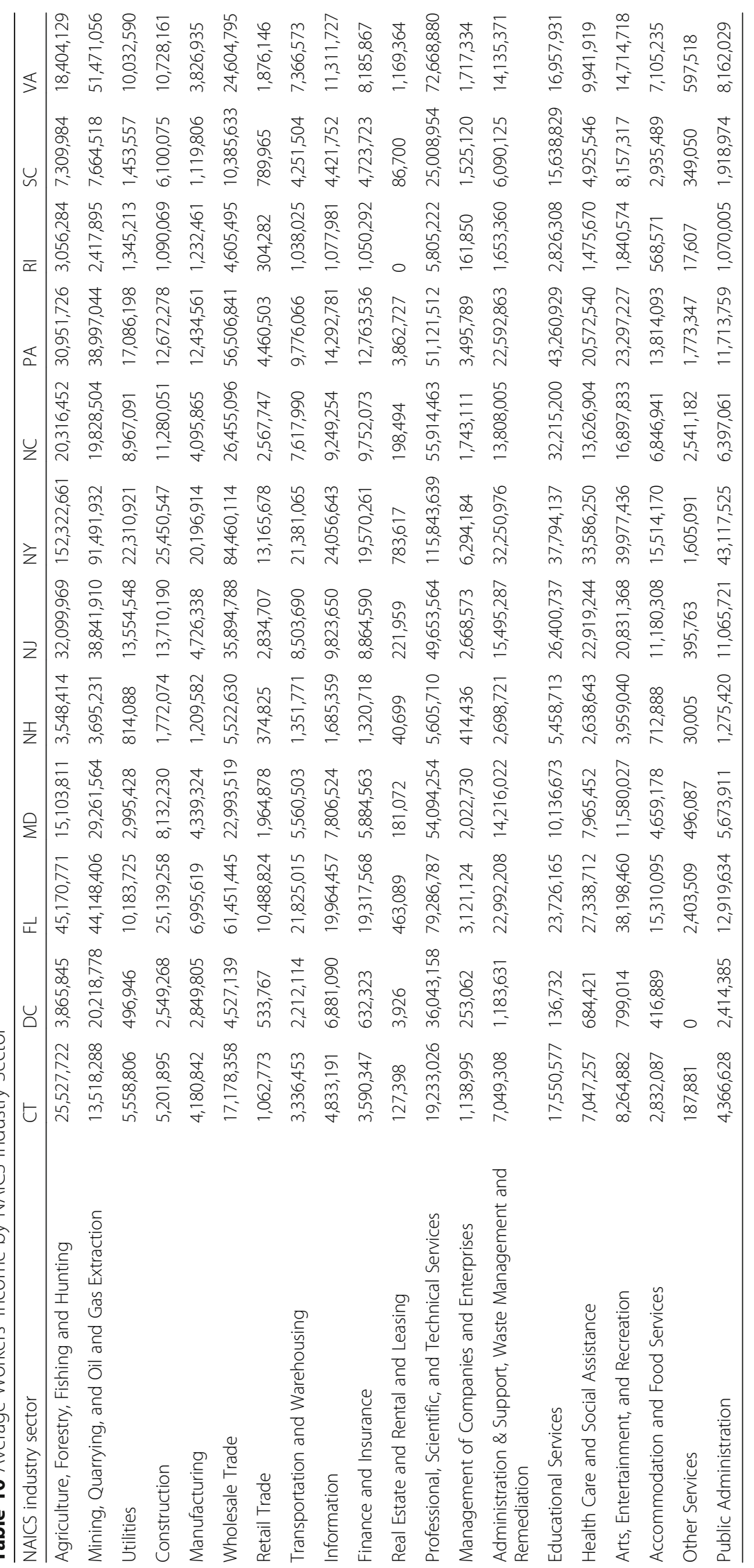




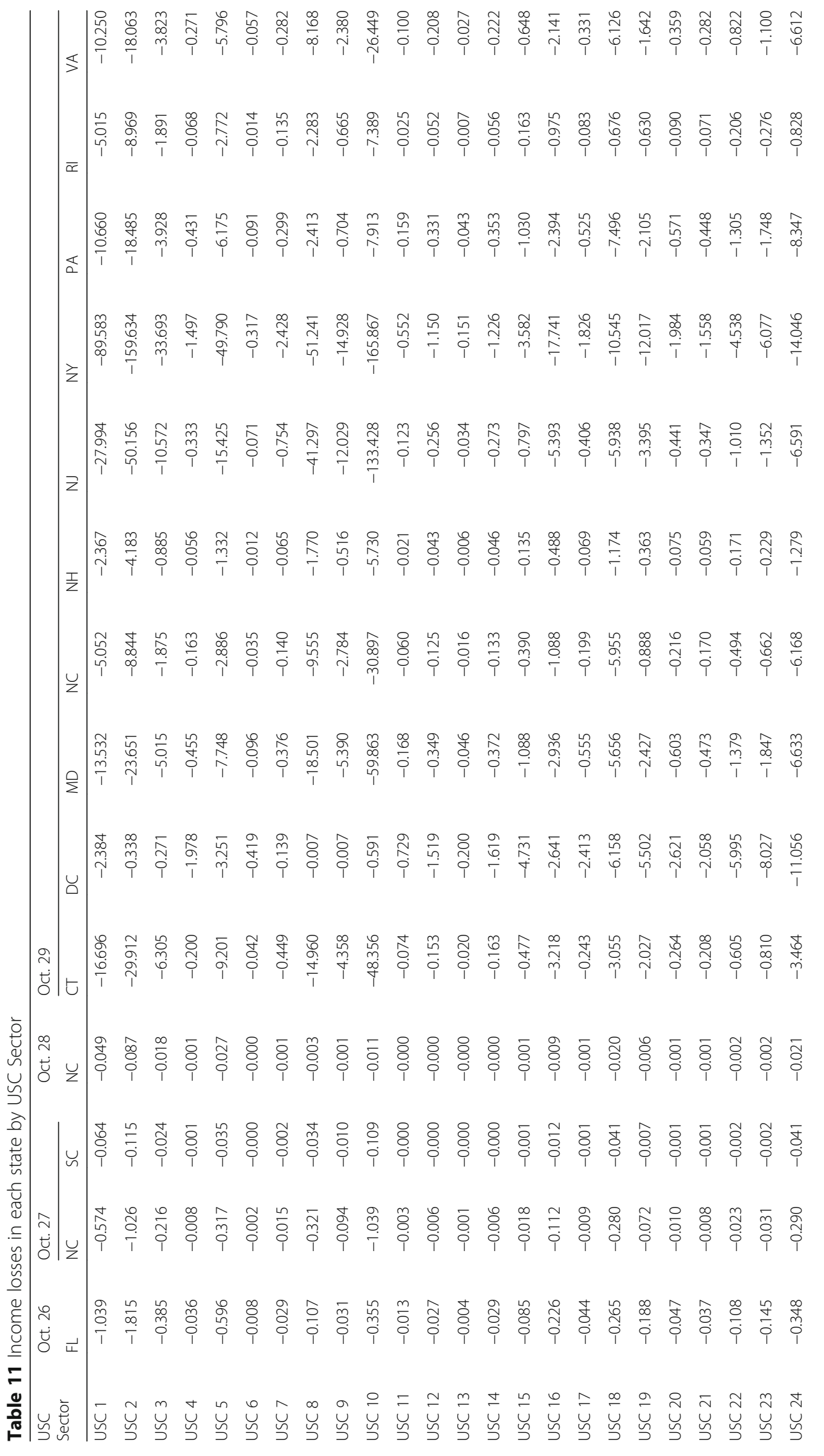




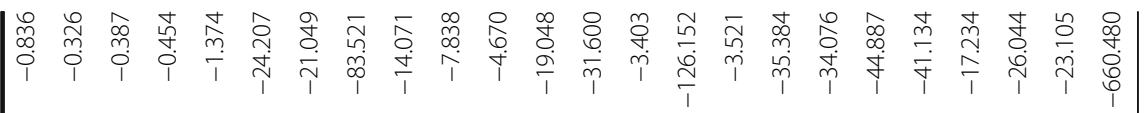

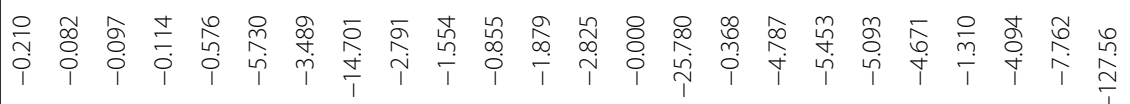

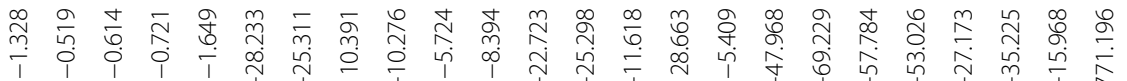

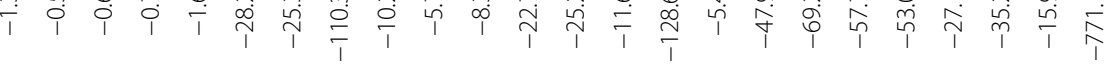

の

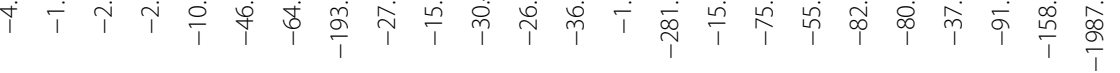

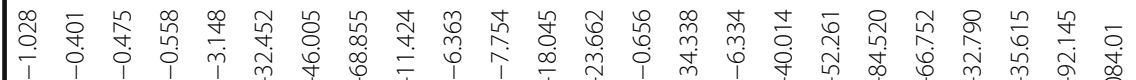

1 $\begin{aligned} & 1 \\ & i\end{aligned}$

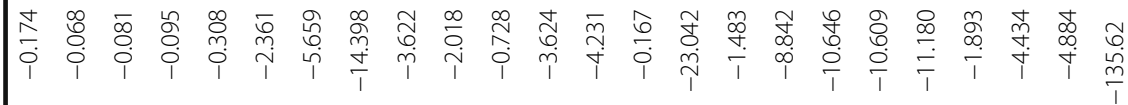

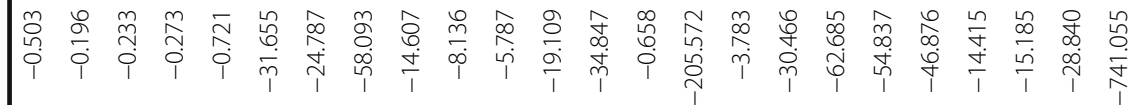

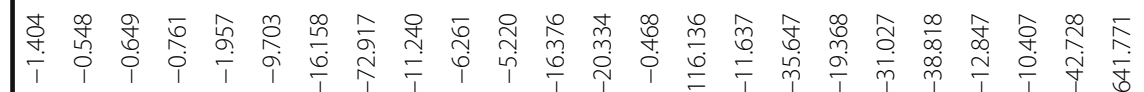

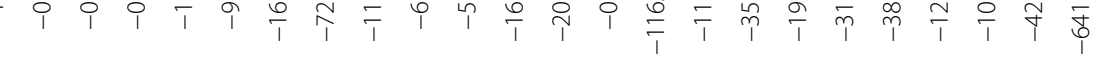

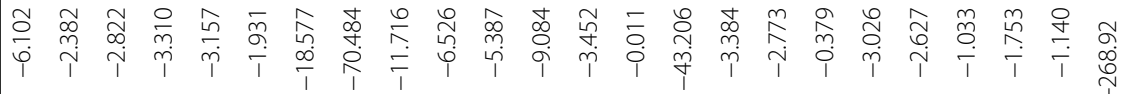

产

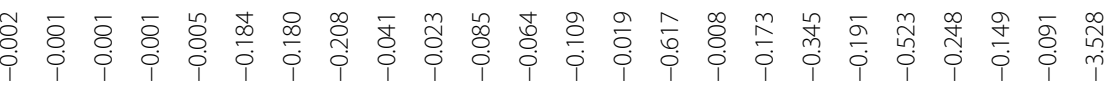

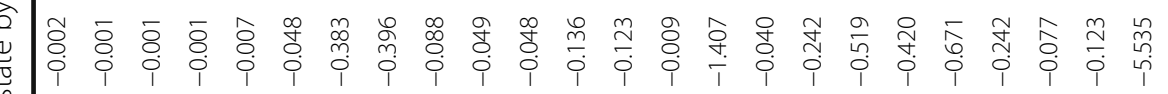

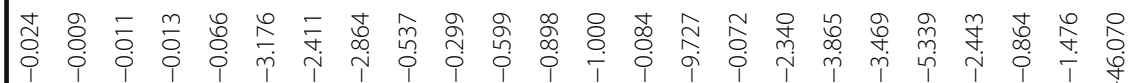

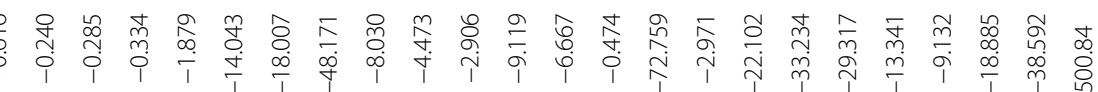

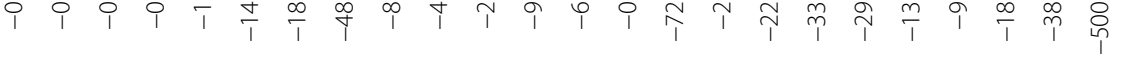

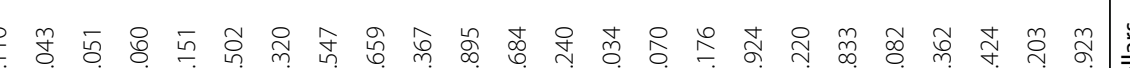




\section{Acknowledgement}

This research was supported by Basic Science Research Program (NRF-2015R1C1A1A01052755) through the National Research Foundation of Korea (NRF) of the Korea Ministry of Education and Climate Change Correspondence Program (2014001310006) of the Korea Ministry of Environment. Also, publication fee of this article was supported by SOltmC and the DGIST R\&D Program of the Ministry of Science, ICT and Future Planning (16-IT) of South Korea. Finally, we sincerely appreciate Professor Harry W. Richardson for his intellectual support on hurricane information used in this study.

\section{Authors' contribution}

All authors contributed equally to this study. All authors read and approved the final manuscript.

\section{Competing interests}

The authors declare that they have no competing interests.

\section{Author details}

'Department of Urban and Regional Planning, University at Buffalo, 228 Hayes Hall, Buffalo, NY 14214-3087, USA.

${ }^{2}$ Future Strategy \& Convergence Research Institute, Korea Institute of Civil Engineering and Building Technology, 283, Goyang-daero, Ilsanseo-gu, Goyang-si, Gyeonggi-do, 10223, South Korea. ${ }^{3}$ International Logistics Research Department, Port \& Logistics Research Division, Korea Maritime Institute (KMI), 26, Haeyang-ro 301 beon-gil Yeongdo-gu, Busan 49111, South Korea.

Received: 16 September 2016 Accepted: 31 January 2017

Published online: 01 March 2017

\section{References}

1 Year After Superstorm Sandy: Quick Economic Facts. (2013). Insurance journal. Available at http://www.insurancejournal. com/news/east/2013/10/29/309538.htm. Accessed 1 Aug 2016.

Aerts, J. C. J. H., Lin, N., Botzen, W., Emanuel, K., \& de Moel, H. (2013). Low-Probability Flood Risk Modeling for New York City. Risk Analysis, 33, 772-788.

de Moel, H., Botzen, W., \& Aerts, J. (2013). Economic and direct losses from Hurricane Sandy. In Cost estimates for flood resilience and protection strategies in New York City (Annals of the New York Academy of Sciences, 1294, pp. 81-89).

FEMA. (2016a). FEMA Disaster Declarations Summany - Open Government Dataset. Available at https://www.fema.gov/ media-library/assets/documents/28318. Accessed 1 Aug 2016.

FEMA. (2016b). Data Feed-Geographic Information System(G/S). Available at http://www.fema.gov/data-feeds?utm_ source=datavizpage\&utm_medium=web\&utm_campaign=datavizgraphic. Accessed 1 Aug 2016.

FEMA. (2016c). Sandy Recovery Office. Available at http://www.fema.gov/sandy-recovery-office. Accessed 1 Aug 2016.

FEMA. (2016d). Two years after Hurricane Sandy: New York recovery by the numbers. Available at http://www. fema.gov/disaster/4085/updates/two-years-after-hurricane-sandy-new-york-recovery-numbers. Accessed 1 Aug 2016.

Fischer, E. M., \& Knutti, R. (2015). Anthropogenic contribution to global occurrence of heavy-precipitation and high-temperature extremes. Nature Climate Change, 5(6), 560-564.

Holtz-Eakin, H. D. J. (2005). Statement in AFTER THE HURRICANES: IMPACT ON THE FISCAL YEAR 2007 BUDGET. Available at http://www.access.gpo.gov/congress/house/house04ch109.html. Accessed 1 Aug 2016

Kent, J. D. (2006). 2005 Louisiana Hurricane Impact Atlas Volume 1. Louisiana Geographic Information Center. Available at http://lagic.lsu.edu/images/hurricanes/2005_LAGIC_HURRICANE_ATLAS.pdf. Accessed 1 Aug 2016.

Knabb, R. D., Brown, D. P., \& Rhom, J. R. (2006). Tropical Cyclone Report Hurricane Rita: 18-26 September 2005. National Hurricane Center. Available at http://www.nhc.noaa.gov/ms-word/TCR-AL182005_Rita.doc. Accessed 1 Aug 2016.

Kunz, M., Mühr, B., Kunz-Plapp, T., Daniell, J. E., Khazai, B., Wenzel, F., Vannieuwenhuyse, M., Comes, T., Elmer, F., Schröter, K., Fohringer, J., Münzberg, T., Lucas, C., \& Zschau, J. (2013). Investigation of superstorm Sandy 2012 in a multi-disciplinary approach. Natural Hazards and Earth System Sciences, 13, 2579-2598

Lewis, S. C., \& Karoly, D. J. (2013). Anthropogenic contributions to Australia's record summer temperatures of 2013. Geophysical Research Letters, 40(14), 3705-3709.

Louisiana Geographic Information Center. (2005). Louisiana Hurricane Impact Atlas, Vol. 1. Available at http://lagic.lsu. edu/images/hurricanes/2005_LAGIC_HURRICANE_ATLAS.pdf. Accessed 1 Aug 2016.

Mantell, N. H., Seneca, J. J., Lahr, M. L., \& Irving, W. (2013). The economic and fiscal impacts of Hurricane Sandy in New Jersey: a macroeconomic analysis. New Brunswick: Rutgers Regional Report. 34.

Miller, R. E., \& Blair, P. D. (2009). Input-output Analysis: Foundations and Extensions (2nd ed.). New York: Cambridge University Press.

National Hurricane Center of National Weather Service. (2007). Tropical Weather Summary-2005 Web Final. Available at http://www.nhc.noaa.gov/archive/2005/tws/MIATWSAT_nov_final.shtml. Accessed 1 Aug 2016.

National Research Council. (1999). The Impacts of Natural Disasters: A Framework for Loss Estimation. Available at http:// www.nap.edu/catalog/6425.html. Accessed 1 Aug 2016.

Nordhaus, W. D. (2006). The Economics of Hurricanes in the United States (NBER Working Paper No. 12813). Cambridge: National Bureau of Economic Research.

Otto, F. E., Massey, N., Oldenborgh, G. J., Jones, R. G., \& Allen, M. R. (2012). Reconciling two approaches to attribution of the 2010 Russian heat wave. Geophysical Research Letters, 39(4).

Pall, P., Aina, T., Stone, D. A., Stott, P. A., Nozawa, T., Hilberts, A. G., Lohmann, D., \& Allen, M. R. (2011). Anthropogenic greenhouse gas contribution to flood risk in England and Wales in autumn 2000. Nature, 470(7334), 382-385. 
Park, J. Y. (2007). The Supply-Driven Input-output Model: A Reinterpretation and Extension (presented at 46thAnnual Meeting of the Western Regional Science Association, Newport Beach, CA, USA, February 21-24).

Park, J. Y. (2008). The Economic Impacts of Dirty- Bomb Attacks on the Los Angeles and Long Beach Ports: Applying the Supply-driven NIEMO (National Interstate Economic Model). Journal of Homeland Security and Emergency Management, 5(1), Article 21.

Park, C., \& Park, J. Y. (2016). Panama Canal expansion, US trade diversion from west coast seaports and urban innovation. Journal of Open Innovation: Technology, Market, and Complexity, 2, 12.

Park, J. Y., Cho, J., Gordon, P., Moore, J. E., Richardson, H. W., \& Yoon, S. (2011). Adding a freight network to a national interstate input-output model: a TransNIEMO application for California. Journal of Transport Geography, 19(6), 1410-1422.

Park, J. Y., Gordon, P., Moore, J. E., II, Richardson, H. W., \& Wang, L. (2007). Simulating The State-by-State Effects of Terrorist Attacks on Three Major U.S. Ports: Applying NIEMO (National Interstate Economic Model). In H. W. Richardson, P. Gordon, \& J. E. Moore II (Eds.), The Economic Costs and Consequences of Terrorism (pp. 208-234). Cheltenham: Edward Elgar.

Park, J. Y., Gordon, P., Kim, S. J., Kim, Y. K., Moore, J. E., II, \& Richardson, H. W. (2008). Estimating the State-by-State Economic Impacts of Hurricane Katrina. In H. W. Richardson, P. Gordon, \& J. E. Moore II (Eds.), Natural Disaster Analysis after Hurricane Katrina (pp. 147-186). Cheltenham: Edward Elgar.

Park, J. Y., Gordon, P., Moore, J. E., II, \& Richardson, H. W. (2009). A two-step approach to estimating state-to-state commodity trade flows. The Annals of Regional Science, 43, 1033-1072.

Park, J. Y., Gordon, P., Moore, J. E., II, \& Richardson, H. W. (2013). The Interregional and Interindustry Impacts of the Gulf Oil Spill: Applying the National Interstate Economic Model (NIEMO). Journal of Homeland Security and Emergency Management, 10(1), 231-244.

Park, J. Y., Richardson, H. W., Park, C. K., \& Son, M. (2014). Hurricane Sandy. In H. W. Richardson, J. Y. Park, J. E. Moore II, \& Q. Pan (Eds.), National Economic Impact Analysis of Terrorist Attacks and Natural Disasters (pp. 204-220). Cheltenham: Edward Elgar.

Park, J. Y., Kwon, C., \& Son, M. (2014). Economic Implications of the Canada-US Border Bridges: Applying a Transportation-Combined Binational Input-output Model for Canada and the U.S. Research in Transportation Business and Management, 11, 123-133.

Park, J. Y., Gordon, P., Kim, Y. K., Moore, J. E., Il, \& Richardson, H. W. (2017). The Temporal Regional Economic Impacts of a Hurricane Disaster on Oil Refinery Operations: A FlexNIEMO approach (in press). In A. Abbas, M. Tambe, \& D. von Winterfeldt (Eds.), Improving Homeland Security Decisions. New York: Cambridge University Press.

Richardson, H. W., Park, J. Y., Moore, J. E., II, \& Pan, Q. (2014). National Economic Impact Analysis of Terrorist and Natural Disasters. Cheltenham: Edward Elgar.

Sallenger, A. H., Jr., Doran, K. S., \& Howd, P. A. (2012). Hotspot of accelerated sea-level rise on the Atlantic coast of North America. Nature Climate Change, 2(12), 884-888.

Sippel, S., \& Otto, F. E. (2014). Beyond climatological extremes-assessing how the odds of hydro meteorological extreme events in South-East Europe change in a warming climate. Climatic Change, 125(3-4), 381-398.

Stott, P. A., Stone, D. A., \& Allen, M. R. (2004). Human contribution to the European heatwave of 2003. Nature, 432(7017), 610-614.

Weis, D. J., \& Weidman, J. (2012). An Ounce of Prevention: Increasing Resiliency to Climate-Related Extreme Weather. Center for American Progress. Available at http://www.americanprogress.org/issues/green/news/2012/12/17/48398/ an-ounce-of-prevention-increasing-resiliency-to-climate-related-extreme-weather/. Accessed 1 Nov 2013.

Won, D., Yoo, S., Yoo, H., \& Lim, J. (2015). Complex adaptive systems approach to sewol ferry disaster in Korea. Journal of Open Innovation: Technology, Market, and Complexity, 2015(1), 1.

Zandi, M. (2012). The Economic Impact of Sandy. Available at https://www.moodys.com/Publishinglmages/MCO/ ProductAttachments/Econ_Impact_of_Sandy.pdf. Accessed 1 Dec 2016.

\section{Submit your manuscript to a SpringerOpen ${ }^{\circ}$ journal and benefit from:}

- Convenient online submission

- Rigorous peer review

- Immediate publication on acceptance

- Open access: articles freely available online

- High visibility within the field

- Retaining the copyright to your article

Submit your next manuscript at $>$ springeropen.com 